\title{
Unexpected genetic diversity revealed in the Eucalyptus canker pathogen
}

\section{Teratosphaeria gauchensis}

\author{
M. N. CORTINAS, I. BARNES, B. D. WINGFIELD and M. J. WINGFIELD
}

Department of Genetics, Forestry and Agriculture Biotechnology Institute (FABI), University of Pretoria, PBag

X20, Hatfield, Pretoria 0028, South Africa.

Corresponding author:

E-mail: brenda.wingfield@fabi.up.ac.za

Tel: $+27-12-420-6471$

Fax: $+27-12-420-3960$

Present address:

University of Pretoria

Forestry and Agricultural Biotechnology Institute (FABI)

PBag X20,

Hatfield,

Pretoria 0028

South Africa

\begin{abstract}
Teratosphaeria gauchensis causes a serious canker disease on Eucalyptus spp. in plantations in South America and Africa. The pathogen is closely related to, but distinct from T. zuluensis that causes a similar stem canker disease on Eucalyptus. The objective of this study was to use 10 previously developed polymorphic microsatellite markers to study the population diversity of $T$. gauchensis, based on collections of the fungus made in Argentina and Uruguay. The alleles were size -analyzed to determine population genetic parameters of the $T$. gauchensis populations. The results showed that isolates from the two collection sites represent the same population. Overall, the genetic diversity amongst isolates was higher than expected and inconsistent with the notion that the pathogen represents a recent introduction into South America.
\end{abstract}

Additional keywords: ascomycete, Eucalyptus stem canker, forest pathogen, Teratosphaeria gauchensis, Teratosphaeria zuluensis, microsatellites, population structure. 
Teratosphaeria gauchensis (M.N. Cortinas, Crous \& M.J. Wingf.) M.J Wingf. \& Crous and the related Teratosphaeria zuluensis (M.J. Wingf., Crous \& T.A. Cout.) M.J. Wingf. \& Crous cause a disease known as Coniothyrium canker on Eucalyptus spp. Teratosphaeria zuluensis was the first of these fungi to be described after it was discovered causing serious damage to the stems of clonally propagated Eucalyptus grandis in the Kwa-Zulu Natal province of South Africa (Wingfield et al. 1997). The disease spread rapidly in the 1990's and became one of the most serious impediments to Eucalyptus plantation forestry in that country (Old et al. 2003).

Due to the serious economic impact of Coniothyrium canker on plantations in South Africa, there were various studies undertaken to better understand the relevance and biology of T. zuluensis (van Zyl, 1999, van Zyl et al. 2002). Some years later, a very similar disease was discovered on $E$ grandis clones in Argentina and Uruguay and surprisingly, the causal agent was found to be different to T. zuluense (Cortinas et al. 2006b). The causal agent of the disease was described as Teratosphaeria gauchensis. Teratosphaeria gauchensis and T. zuluensis are morphologically almost indistinguishable and they give rise to the same symptoms after infection. Thus, the only reliable means to distinguish between the two fungi is via DNA sequence comparisons. Both fungi were initially described as mitotic species and residing in the teleomorph genus Mycosphaerella based on phylogenetic inference (Cortinas et al. 2006b; Andjic et al. 2007) but recent taxonomic re-evaluation has relegated them to anamorphs of Teratosphaeria in the Teratosphaeriaceae (Crous et al. 2007; Crous et al. 2009).

Teratosphaeria gauchensis causes cankers on young branches and tree trunks although it has also been isolated from leaf spots on E. maidenii and E. tereticornis in Uruguay (Pérez et al. 2009a). The typical stem and trunk lesions caused by this fungus are necrotic and have a characteristic dark oval shape (Cortinas et al. 2006b). The extent of the lesions varies depending on the susceptibility of the infected trees. Severe infections arise from small cankers that merge to cover large areas of the trunk. Both the soft tissue and wood become malformed resulting in retarded growth and girdling can be observed at the tree tops. Kino pockets are formed as part of the defence response of the trees. Kino that exudes from the cankers can cause the stems to become a black colour. In some cases, diseased trees also produce epicormic shoots alongside the cankers that can cause the terminal parts of the branches and stems to die (Wingfield et al.1997; Cortinas et al. 2006b).

Very little is known regarding the biology of $T$. gauchensis. It is presumed that the fungus exists in a haploid state (Wingfield et al. 1997; Crous, 1998; Crous et al. 2004; 2006). In nature, only 
asexual pycnidia are found on the bark lesions. These structues give rise to mitospores (conidia) that are presumably responsible for short distance dispersal, as is the case for closely related fungi (Feau et al. 2005; Milgate et al. 2005; Hunter et al. 2008). Sexual structures have never been observed in nature nor have they been produced in culture.

The origin of $T$. gauchensis is not known. Its distribution is limited to Uganda and Ethiopia (Gezahgne 2003; Gezahgne et al. 2005), Argentina and Uruguay (Gezahgne et al. 2004; Cortinas et al. 2006b) and Hawaii (Cortinas et al. 2004). It is has also never been found on any host other than Eucalyptus species, which is an exotic species in all these countries. The current distribution of $T$. gauchensis does not overlap with the distribution of the sibling species T. zuluensis (Cortinas et al. 2006b). The fact that Eucalyptus species are not native to any of the countries where T. gauchensis has been found and that $T$. gauchensis has a close phylogenetic relationship to other Teratosphaeria Eucalyptus-specific pathogens, it is likely, that this fungus is yet be discovered in the native range of Eucalyptus. If that is the case, then one would expect to find fungal populations with low genetic diversity in areas where it has been introduced, which is true for the related T. nubilosa (= M. nubilosa) (Pérez et al. 2009).

The aim of this study was to investigate the population diversity and structure of $T$. gauchensis found on non-native Eucalyptus in plantations of Argentina and Uruguay where the associated disease has been particularly serious. To achieve this goal, ten polymorphic microsatellite markers, recently developed for this species (Cortinas et al. 2008), were used to calculate estimates of haplotype richness and evenness, haplotypic diversity and genetic differentiation for isolates collected in Argentina and Uruguay.

\section{Sampling and isolations}

Necrotic lesions on the bark of infected Eucalyptus clones were sampled from plantations in the neighbouring provinces of Entre Ríos, Corrientes and Misiones in Argentina and from two areas (Rivera and Paysandú), in the Northern part of Uruguay. The sampling area covered a range of approximately $450 \mathrm{~km}$ in a North-South direction and $300 \mathrm{Km}$ in an East- West direction (Table 1). Samples were collected as part of a disease evaluation project in Uruguay and Argentina between 1999 and 2005. Samples were taken from lesions on the stems of randomly chosen trees approximately $2 \mathrm{~m}$ above the ground. 
One hundred and thirty one single conidial isolations were made from lesions of 23 trees in Argentina and 43 trees in Urugauy (Table 1) as described previously (Cortinas et al. 2006a). These single conidial cultures were deposited in the culture collection (CMW) of the Forestry and Agricultural Biotechnology Institute (FABI), University of Pretoria, where they are maintained in longterm storage facilities.

\section{DNA extraction and amplification of microsatellite loci}

Single conidial isolates were obtained and DNA from these isolates was extracted as described by Cortinas et al. (2006a). Ten pairs of fluorescently labelled primer sets for 10 polymorphic microsatellite loci of T. gauchensis (Cortinas et al. 2008) were used in this study. The microsatellite loci were originally subscribed to GenBank as “K. gauchensis" followed by a number. In this publication they are abbreviated in the tables as " $\mathrm{Kg}$ " loci, followed by a number. The microsatellite loci were amplified by Polymerase Chain Reaction (PCR) and the amplified products were sizeseparated on an ABI 3100 Automated DNA Sequencer (Applied Biosystems, Foster City, USA) using GENSCAN LIZ 500 (-250) (Applied Biosystems) as internal size standard as described in Cortinas et al. (2008).

Thirty-eight isolates were analysed from Argentina. These included 10 isolates from the Entre Rios province, 17 from the Corrientes province, eight from the Misiones of Argentina and three from undefined source within these provinces. Ninety-three isolates were obtained and analysed from Uruguay including 33 from the Paysandú department and 60 from the Rivera department (Table 1). GENEMAPPER, version 3.0 (Applied Biosystems) software package was used to carry out the fragment size analysis. Based on size differences of the amplicons produced for each locus, different alleles were identified. For further analyses, each allele was designated by their size in nucleotides or by a letter of the alphabet.

The gene diversity $(H)$, genotypic diversity $(G)$, richness and evenness, population differentiation and trecombination analyses using linkage disequilibrium (LD) and Index of Association $\left(I_{A}\right)$ were performed as in Cortinas et al. 2008. 


\section{Allele and genetic diversity}

Forty- three different alleles were recovered for the 131 isolates of the T. gauchensis collected and analysed. Individually, 31 different alleles were recovered from the Argentinean samples and 35 from the Uruguayan population (Table 2). The number of alleles at individual loci, for both populations, ranged from two to eight. Private alleles were observed in both populations; five from Argentina and nine from Uruguay. The majority of these private alleles were present with frequencies higher than $3 \%$. No monomorphic loci were observed.

The gene diversity $(\mathrm{H})$ calculated for T. gauchensis was 0.43 in Argentina and 0.42 in Uruguay (Table 2). Ninety-one different genotypes were identified across the two $T$. gauchensis populations (Table 2). One genotype was found to be shared between the Argentinean and Uruguayan populations. The number of repeated genotypes was $26.3 \%$ for the Argentinean population and $33.3 \%$ for the Uruguayan population. The maximum genotypic (haplotype) diversity was similar for Uruguay $(\hat{G}=50 \%)$ and Argentina $(\hat{G}=54 \%)$ (Table 2). The $t$ test $(\mathrm{P}<0.05)$ showed no significant differences between the genotypic diversities of the Argentinean and Uruguayan populations.

The heterogeneity within the populations (relative richness and evenness) values obtained were $S=3.29$ and $\mathrm{V}^{\prime}=0.965$ for Argentina and $\mathrm{S}=3.96$ and $\mathrm{V}^{\prime}=0.967$ for Uruguay, very similar for both populations. Both had regression values $=1$ and similar slopes $(\beta=2.64$ for Argentina and $\beta=2.43$ for Uruguay). Together, these results showed moderate to high haplotype heterogeneity and a high level of evenness (groups of clones of similar membership size). The majority of repeated haplotypes in Argentina and Uruguay formed groups of two individuals.

\section{Population differentiation and assignment tests}

The allelic frequencies across populations were compared by calculating the differences in allelic frequencies per locus and between pairwise populations (Table 3). The analysis of the loci showed that the frequencies of the alleles between the populations of Argentina and Uruguay were only significantly different at one (Locus 6) of 10 loci. The theta value of $0.011(\mathrm{P}<0.05)$ indicated no differentiation among the Argentinean and Uruguayan populations. 
No admixture patterns were detected using STRUCTURE as clusters were not detected. The assignment diagrams showed that the majority of individuals assigned to all different $\mathrm{K}$ groups in similar proportions in the tested range between $\mathrm{K}=1$ to $\mathrm{K}=10$.

\section{Recombination analyses}

In T. gauchensis, low LD was found using two-locus pairwise analyses: zero out of 45 comparisons in the Argentinean population and four of 45 comparisons in the Uruguayan population showed linkage disequilibrium (Table 4). The results obtained from the multilocus Index of Association $\left(I_{A}\right)$ analyses were comparable to the LD results calculated using the pairwise method (Table 4). The observed values of $I_{A}$ in $T$. gauchensis fell within the randomized distribution of allelic frequencies suggesting that recombination could be occurring in both $T$. gauchensis populations.

\section{Discussion}

Teratosphaeria gauchensis is a pathogen of growing importance to a rapidly expanding Eucalyptus plantation industry in South America. This study provides the first consideration of its genetic diversity and thus, long term durability of resistance in intensively propagated planting stock. As such, populations of $T$. gauchensis from Argentina and Uruguay showed a genetic structure that is very different to one expected for a recently introduced pathogen. These populations contained moderate to high level of genetic variation, homogeneous distribution of haplotypes, no differentiation between populations and indications that recombination is occurring.

The moderate to high levels of genetic diversity found in the T. gauchensis populations from South America were unexpected as the disease was only discovered in Argentina and Uruguay in the last two decades. Because of its occurrence on Eucalyptus trees, it was thought to have been introduced into these countries relatively recently, probably from the native range of Eucalyptus. Thus, a low genetic diversity and a small number of predominant haplotypes (clones) were expected in the populations of $T$. gauchensis. This would be similar to a number of other closely related Eucalyptus pathogens recently reported in Uruguay (Balmelli et al. 2004; Pérez et al. 2009). For example, the Eucalyptus leaf blotch pathogen T. nubilosa, was found to be clonal, which suggests a recent, localized introduction in the area (Pérez et al. 2009). 
The levels of genetic diversity of $T$. gauchensis found in this study were comparable with the genetic diversities of other phylogenetically related Mycosphaerella and Teratosphaeria species from their native ranges. These species include M. musicola (Hayden et al. 2003b; 2005; ZandjanakouTachin et al. 2009), M. fijiensis (Carlier et al. 1996; Hayden et al. 2003a) and T. nubilosa (Hunter et al. 2008; 2009). Interestingly, with the exception of T. gauchensis, all these species have well characterized sexual states that would promote their genetic diversity.

Results of this study showed evidence of recombination in the studied $T$. gauchensis population from Argentina. This result was unexpected as sexual structures have never been found in the field for this fungus. Nonetheless, there is precedence for finding evidence of recombination in apparently asexual fungi (Taylor et al. 1999; Zhou et al. 2007). From this study we can conclude that $T$. gauchensis in all likelihood has a mixed mode of reproduction and has asexual and sexual reproductive structures similar to the most closely related Mycosphaerella spp. (Cortinas et al. in press; Crous et al. 2004; 2006; Hunter et al. 2008; Pérez et al. 2010).

Population genetic analyses showed that the two collections of isolates from Argentina and Uruguay can be considered as part of the same genetic pool, rather than two separate and unrelated populations. Thus, the differentiation tests showed weak to no differentiation between the two $T$. gauchensis populations. These results were further supported by the assignment tests whereby the individuals from Argentina and Uruguay, regardless of the number of clusters tested, were separated in equal proportions among clusters, indicating a lack of population structure for the isolates (Pritchard et al. 2000).

Analyses of $T$. gauchensis isolates from Argentina and Uruguay are not compatible with the hypothesis that this is a recently introduced pathogen. One possible explanation for this result is that the fungus originated in Australasia where Eucalyptus is native, as in the case of T. nubilosa (Hunter et al. 2008; 2009). This would be consistent with recent well documented examples of new Eucalyptus pathogens first being described from plantations outside the native range of Eucalyptus and later being discovered in Australia (Wingfield et al. 1996; Burgess et al. 2007). An alternative interpretation is that the pathogen has undergone a host shift from native Myrtaceae in Argentina and Uruguay. There are a growing number of Eucalyptus pathogens that have undergone host jumps (Slippers et al. 2005) from native Myrtaceae and Melastomataceae (Myrtales) in countries where Eucalyptus spp. have been planted as exotics (Wingfield 2003; Wingfield et al. 2008; Glen et al. 2007) Many of these examples 
are from South America including Uruguay (Pérez 2008). The most recent examples are Quambalaria eucalypti (Pérez et al.2008), Neofusicoccum eucalyptorum (Pérez et al. 2009b), Puccinia psidii (Pérez et al.2010a, in press) and members of Botryosphaeriaceae (Pérez et al.2010b). It would not be unusual for T. gauchensis to have behaved in a similar fashion.

\section{Acknowledgements}

We are grateful for the assistance from forestry companies in Uruguay and Argentina and express our gratitude to Sophie Arnaud-Haond for her comments and help using GENCLONE 2.O. We also acknowledge the National Research Foundation (NRF), members of the Tree Protection Co-operative Program (TPCP), the THRIP initiative of the Department of Trade and Industry and the DST/NRF Centre of Excellence in Tree Health Biotechnology (CTHB), University of Pretoria, South Africa for financial support.

\section{References}

Agapow PM, Burt A (2001) Indices of multilocus linkage disequilibrium. Molecular Ecology Notes 1, $101-2$

Andjic V, Barber PA, Carnegie AJ, Hardy GEStJ, Wingfield MJ, Burgess TI (2007) A morphological and phylogenetic reassessment of the genus Phaeophleospora and the resurrection of the genus Kirramyces. Mycological Research 111, 1184-1198.

Arnaud-Haond S, Belknir K (2007) GENCLONE 1.0: a new program to analyse genetics data on clonal organisms. Molecular Ecology Notes 7, 15-17.

Arnaud-Haond S, Duarte CM, Alberto F, Serrão (2007) Standardizing methods to address clonality in population studies. Molecular Ecology 16, 5115-5139.

Balmelli G, Marroni V, Altier N, Garcia R (2004) Potencial del mejoramiento genético para el manejo de enfermedades en Eucalyptus globulus. Serie Técnica INIA Tacuarembó, Uruguay 143, 143.

Burgess TI, Andjic V, Wingfield MJ, Hardy GEStJ (2007) The eucalypt leaf blight pathogen Kirramyces destructans discovered in Australia. Australasian Plant Disease Notes 2, 141144. 
Carlier J, Lebrun MH, Zapater MF, Dubois C, Mourichon X (1996) Genetic structure of the global population of banana black streak fungus, Mycosphaerella fijiensis. Molecular Ecology 5, 499-510.

Chen RS, Boeger JM, McDonald BA (1994) Genetic stability in a population of a plant pathogenic fungus over time. Molecular Ecology 3, 209-18.

Cortinas MN, Barnes I, Wingfield MJ Wingfield BD (2010) Genetic diversity in the Eucalyptus stem pathogen Teratosphaeria zuluensis.Australasian Plant Pathology (in press).

Cortinas MN, Burgess T, Dell B, Xu D, Crous PW, Wingfield BD, Wingfield MJ (2006a) First record of Colletogloeopsis zuluense comb. nov., causing stem canker of Eucalyptus in China. Mycological Research 110, 229-236.

Cortinas MN, Crous PW, Wingfield BD, Wingfield MJ (2006b) Multilocus gene phylogenies and phenotypic characters distinguish two species within the Colletogloeopsis zuluensis complex associated with Eucalyptus stem cankers. Studies in Mycology 55, 135-148.

Cortinas MN, Koch N, Thane J, Wingfield BD, Wingfield MJ (2004) First record of the Eucalyptus stem canker pathogen, Coniothyrium zuluense from Hawaii. Australasian Plant Pathology 33, 309-312.

Cortinas MN, Wingfield BD, Wingfield MJ (2008) Microsatellite markers for the Eucalyptus stem canker fungal pathogen Kirramyces gauchensis. Molecular Ecology Resources 8, 590-592.

Crous PW (1998) Mycosphaerella spp. and their anamorphs associated with leaf spot diseases of Eucalyptus. Mycologia Memoir 21, 1-170.

Crous PW, Braun U, Groenewald JZ (2007) Mycosphaerella is polyphyletic. Studies in Mycology, 58: 1-32.

Crous PW, Groenewald JZ, Mansilla JP, Hunter GC, Wingfield MJ (2004) Phylogenetic reassessment of Mycosphaerella spp. and their anamorphs occurring on Eucalyptus. Studies in Mycology 50, 195-214.

Crous PW, Groenewald JZ, Summerell BA, Wingfield BD, Wingfield MJ (2009) Co-occurring species of Teratosphaeria on Eucalyptus. Persoonia 22, 38-48. 
Crous PW, Wingfield MJ, Mansilla JP, Alfenas AC, Groenewald JZ (2006) Phylogenetic reassessment of Mycosphaerella spp. and their anamorphs occurring on Eucalyptus. II. Studies in Mycology 55, 99-131.

Falush D, Stephens M, Pritchard JK (2003) Inference of Population Structure Using Multilocus Genotype Data: Linked Loci and Correlated Allele Frequencies. Genetics 164, 1567-1587.

Feau N, Hamelin RC, Vamdecasteele C, Stanosz GR, Bernier L (2005) Genetic structure of Mycosphaerella populorum (Anamorph Septoria musiva) populations in North-Central and Northeastern North America. Phytopathology 95, 608-616.

Gezahgne A, Cortinas MN, Wingfield MJ, Roux J (2005) Characterisation of the Coniothyrium stem canker pathogen on Eucalyptus camaldulensis in Ethiopia. Australasian Plant Pathology 34, $1-6$.

Gezahgne A, Roux J, Thu PQ, Wingfield MJ (2004) Coniothyrium stem canker of Eucalyptus, new to Argentina and Vietnam. South African Journal of Science 99, 587-588.

Gezahgne A (2003) Diseases of exotic plantations Eucalyptus and Pinus species in Ethiopia. South African Journal of Science 99, 29-33.

Glen M, Smith AH, Langrell SRH, Mohammed CL (2007) Development of nested polymerase chain reaction detection of Mycosphaerella spp. and its application to the study of leaf disease in Eucalyptus plantations. Phytopathology 97, 132-144.

Hayden HL, Carlier J, Aitken EAB (2003a) Genetic structure of Mycosphaerella fijiensis populations from Australia, Papua New Guinea and the Pacific Islands. Plant Pathology 52, 703-712.

Hayden HL, Carlier J, Aitken EAB (2003b) Population differentiation in the banana leaf spot pathogen Mycosphaerella musicola, examined at a global scale. Plant Pathology 52, 713-9.

Hayden HL, Carlier J, Aitken EAB (2005) The genetic structure of Australian populations of Mycosphaerella musicola suggests restricted gene flow at the continental scale. Phytopathology 5, 489-498.

Hunter GC, van der Merwe NA, Burgess TI, Carnegie AJ, Wingfield BD, Crous PW, Wingfield MJ (2008) Global movement and population biology of Mycosphaerella nubilosa infecting leaves of cold-tolerant Eucalyptus globulus and E. nitens. Plant Pathology 57, 235-242. 
Hunter GC, Crous PW, Carnegie AJ, Wingfield MJ (2009) Teratosphaeria nubilosa, a serious leaf disease pathogen of Eucalyptus spp. in native and introduced areas. Molecular Plant Pathology 10, 1-14.

Milgate AW, Vaillancourt RE, Mohammed C, Powell M, Potts BM (2005) Genetic structure of a mycosphaerella cryptica population. Australasian Plant Pathology 34, 345-354.

Nei M, 1973. Analysis of gene diversity in subdivided populations. Proceedings of the National Academy of Sciences USA 70, 3321-3.

Old KM, Wingfield MJ, Yuan ZQ (2003) A manual of diseases of eucalypts in South-East Asia. Center for International Forestry Research, Bogor, Indonesia.

Pérez C (2008) Relationship between pathogens of Eucalyptus and native Myrtaceae in Uruguay. Doctoral Thesis. University of Minnesota. Saint Paul. 133 p.

Pérez CA, Altier N, Simeto S, Wingfield MJ, Blanchette RA (2010a) Puccinia psidii on cultivated Eucalyptus and native Myrtaceae in Uruguay. Mycological Progress, in press.

Pérez CA, de Beer ZW, Altier NA, Wingfield MJ, Blanchette RA (2008) Discovery of the eucalypt pathogen Quambalaria eucalypti infecting a non-Eucalyptus host in Uruguay. Australasian Plant Pathology 37, 600-604.

Pérez CA, Wingfield MJ, Altier NA, Blanchette RA (2009a) Mycosphaerellaceae and Teratosphaeriaceae associated with Eucalyptus leaf diseases and stem cankers in Uruguay. Forest Pathology 39, 349-360.

Pérez CA, Wingfield MJ, Slippers B, Altier NA, Blanchette RA (2009b) Neofusicoccum eucalyptorum, a Eucalyptus pathogen, on native Myrtaceae in Uruguay. Plant Pathology 58, 964-970.

Pérez CA, Wingfield MJ, Slippers B, Altier, NA, Blanchette RA (2010b) Endophytic and cankerassociated Botryosphaeriaceae occurring on non-native Eucalyptus and native Myrtaceae trees in Uruguay. Fungal Diversity 41, 53-69.

Pérez G, Hunter GC, Slippers B, Pérez C, Wingfield BD, Wingfield MJ (2009) Teratosphaeria (Mycosphaerella) nubilosa, the causal agent of Mycosphaerella leaf disease (MLD), recently introduced into Uruguay. European Journal of Plant Pathology 125, 109-118. 
Pérez G, Slippers B, Wingfield BD, Hunter GC, Wingfield MJ (2010) Micro- and macrospatial scale analyses illustrates mixed mating strategies and extensive geneflow in populations of an invasive haploid pathogen. Molecular Ecology 19, 1801-1813.

Slippers B, Stenlid J, Wingfield MJ (2005) Emerging pathogens: fungal host jumps following anthropogenic introduction. Trends in Ecology and Evolution 20, 420-421.

Stoddart JA, Taylor JF (1988) Genotype diversity: Estimation and prediction in samples. Genetics 118, 705-711.

Taylor JW, Jacobson DJ, Fisher MC (1999) The evolution of asexual fungi: reproduction, speciation and classification. Annual Review of Phytopathology 37, 197-246.

Van Zyl LM (1999) Factors associated with Coniothyrium Canker of Eucalyptus in South Africa. PhD thesis, University of the Orange Free State, Bloemfontein.

Van Zyl LM, Coutinho TA, Wingfield MJ (2002) Morphological, cultural and pathogenic characteristics of Coniothyrium zuluense isolates from different plantation regions in South Africa. Mycopathologia 155, 149-153.

Weir BS (1996) Genetic Data Analysis II. Sinauer Associates, Sunderland, MA.

Wingfield MJ, (2003) Increasing threat of diseases to exotic plantation forests in the southern hemisphere: Lessons from Cryphonectria canker. Australasian Plant Pathology 32, 133-139.

Wingfield MJ, Crous PW, Boden D (1996) Kirramyces destructans sp. nov., a serious leaf pathogen of Eucalyptus in Indonesia. South African Journal of Botany 62, 325-327.

Wingfield MJ, Crous PW, Couthinho TA (1997) A serious new canker disease of Eucalyptus in South Africa caused by a new species of Coniothyrium. Mycopathologia 136, 139-145.

Wingfield MJ, Slippers B, Hurley BP, Coutinho TA, Wingfield BD, Roux J (2008) Eucalypt pests and diseases: growing threats to plantation productivity Southern Forests: a Journal of Forest Science 70, 139-144.

Workman PL, Niswander JD (1970) Population studies in South-western Indian tribes. II. Local genetic differentiation in the Papago. American Journal of Human Genetics 22, 24-49.

Wright S (1978) Evolution and the Genetics of Populations, vol.4: Variability Within and Among Natural Populations. Chicago, USA: University of Chicago Press. 
Yeh FC, Yang RC, Boyle T (1999) POPGENE. Version 1.31. Microsoft Windows based freeware for population genetic analysis. University of Alberta, Alberta.

Zandjanakou-Tachin, M,Vroh-Bi I, Ojiambo PS, Tenkouano A, Gumedzoe YM, Bandyopadhyay R (2009) Identification and genetic diversity of Mycosphaerella species on banana and plantain in Nigeria. Plant Pathology 58, 536-546.

Zhou X, Burgess TI, De Beer WZ, Lieutier F, Yart A, Carnegie A, Portales JM, Wingfield BD, Wingfield MJ (2007) High intercontinental migration rates and population admixture in the sapstain fungus Ophiostoma ips. Molecular Ecology 16, 89-99. 
Table 1. List of $T$. gauchensis isolates included in this population study.

\begin{tabular}{lllclcc}
\hline Country & $\begin{array}{l}\text { Province } \\
\text { /Department }\end{array}$ & Host & Collection Period & Collectors & $\begin{array}{c}\text { Number } \\
\text { of trees }\end{array}$ & $\begin{array}{c}\text { Number } \\
\text { of isolates }\end{array}$ \\
\hline Argentina & Total 3 provinces & E. grandis & $\begin{array}{c}2001 / 2003 / 2004 \\
\text { MJ Wingfield/ }\end{array}$ & 23 & 38 \\
& Entre Ríos & & 2003,2004 & MN Cortinas & 12 & 26 \\
& Corrientes & & 2001 & & 1 & 1 \\
& Misiones & 2001 & & 7 & 8 \\
& Undefined within & & & & 3 & 3 \\
& the 3 provinces & & 1999 & & 43 & 93 \\
Uruguay & Total 2 departments & E. grandis & $1999 / 2001 / 2005$ & MJ Wingfield/ & 43 \\
& Paysandú & & $1999,2001,2005$ & MN Cortinas & 23 & 33 \\
& Rivera & & $1999,2001,2005$ & & 20 & 60 \\
\hline
\end{tabular}


Table 2. Allelic frequencies and other diversity indices of the clone-corrected populations from Argentina and Uruguay at $10 \mathrm{~T}$. gauchensis microstellite loci.

\begin{tabular}{|c|c|c|c|}
\hline Loci & Alleles & Argentina & Uruguay \\
\hline \multirow[t]{8}{*}{ Kg-1 } & A & 0.036 & 0.064 \\
\hline & B & 0.179 & 0.302 \\
\hline & $\mathrm{C}$ & 0.536 & 0.508 \\
\hline & $\mathrm{D}$ & 0.179 & 0.079 \\
\hline & $\mathrm{E}$ & 0.036 & 0.016 \\
\hline & $\mathrm{F}$ & & 0.016 \\
\hline & $\mathrm{G}$ & & 0.016 \\
\hline & $\mathrm{H}$ & 0.036 & \\
\hline \multirow[t]{4}{*}{$\mathrm{Kg}-2$} & A & 0.643 & 0.429 \\
\hline & B & 0.215 & 0.427 \\
\hline & $\mathrm{C}$ & 0.143 & 0.127 \\
\hline & $\mathrm{D}$ & & 0.016 \\
\hline \multirow[t]{5}{*}{$\mathrm{Kg}-3$} & A & 0.500 & 0.508 \\
\hline & B & 0.036 & \\
\hline & $\mathrm{C}$ & 0.429 & 0.429 \\
\hline & $\mathrm{D}$ & 0.036 & 0.032 \\
\hline & $\mathrm{E}$ & & 0.032 \\
\hline \multirow[t]{4}{*}{$\mathrm{Kg}-4$} & A & 0.964 & 0.968 \\
\hline & B & 0.036 & \\
\hline & $\mathrm{C}$ & & 0.016 \\
\hline & $\mathrm{D}$ & & 0.016 \\
\hline \multirow[t]{3}{*}{$\mathrm{Kg}-5$} & A & 0.679 & 0.740 \\
\hline & B & 0.286 & 0.222 \\
\hline & $\mathrm{C}$ & 0.036 & 0.032 \\
\hline \multirow[t]{4}{*}{ Kg-6 } & A & 0.607 & 0.571 \\
\hline & B & 0.143 & 0.397 \\
\hline & $\mathrm{C}$ & & 0.032 \\
\hline & $\mathrm{D}$ & 0.250 & \\
\hline \multirow[t]{3}{*}{$\mathrm{Kg}-7$} & A & 0.679 & 0.6825 \\
\hline & B & 0.286 & 0.2857 \\
\hline & $\mathrm{C}$ & 0.036 & 0.0317 \\
\hline \multirow[t]{4}{*}{$\mathrm{Kg}-8$} & A & 0.071 & \\
\hline & B & 0.036 & \\
\hline & $\mathrm{C}$ & 0.893 & 0.984 \\
\hline & $\mathrm{D}$ & & 0.016 \\
\hline \multirow[t]{2}{*}{ Kg-9 } & A & 0.464 & 0.333 \\
\hline & B & 0.536 & 0.667 \\
\hline \multirow[t]{4}{*}{$\mathrm{Kg}-10$} & A & 0.679 & 0.571 \\
\hline & B & 0.321 & 0.381 \\
\hline & $\mathrm{C}$ & & 0.032 \\
\hline & $\mathrm{D}$ & & 0.016 \\
\hline \multicolumn{2}{|l|}{$\mathrm{N}$} & 38 & 93 \\
\hline \multicolumn{2}{|l|}{$\mathrm{Nc}$} & 28 & 63 \\
\hline \multicolumn{2}{|l|}{$\mathrm{Na}$} & 31 & 35 \\
\hline \multicolumn{2}{|c|}{ Number of private alleles } & 5 & 9 \\
\hline \multicolumn{2}{|c|}{$\mathrm{H}$} & 0.43 & 0.42 \\
\hline \multicolumn{2}{|c|}{ Number of different genotypes (haplotypes) } & 28 & 63 \\
\hline \multicolumn{2}{|l|}{ G } & 20.41 & 46.29 \\
\hline
\end{tabular}


$\mathrm{N}=$ Number of isolates (non clone-corrected)

$\mathrm{Nc}=$ Number of haplotypes in the clone-corrected populations

$\mathrm{Na}=$ Observed number of alleles

$\mathrm{H}=$ Gene Diversity according to Nei (1973)

$\mathrm{G}=$ Genotypic Diversity (Stoddart and Taylor, 1988)

$\hat{\mathrm{G}}=\mathrm{G} / \mathrm{N} \%=$ percent maximum diversity

$\mathrm{S}=$ Shannon-Weiner index

$V^{\prime}=$ Evenness index derived from Shannon-Weiner (V')

$\beta$ parameter: Pareto distribution parameter 
Table 3. Pairwise Chi-square comparisons of allelic frequencies between T. gauchensis populations of Argentina and Uruguay.

\begin{tabular}{|c|c|c|c|c|c|c|c|c|c|c|c|}
\hline $\begin{array}{l}\text { Locus/clone corrected } \\
\text { populations }\end{array}$ & & $\mathrm{Kg}-1$ & $\mathrm{Kg}-2$ & $\mathrm{Kg}-3$ & $\mathrm{Kg}-4$ & $\mathrm{Kg}-5$ & Kg-6 & $\mathrm{Kg}-7$ & $\mathrm{Kg}-8$ & Kg-9 & $\mathrm{Kg}-10$ \\
\hline Argentina and Uruguay & $\begin{array}{l}\mathrm{Chi}^{2} \\
\mathrm{df}\end{array}$ & $\begin{array}{c}6.63 \\
7\end{array}$ & $\begin{array}{c}4.73 \\
3\end{array}$ & $\begin{array}{c}3.15 \\
4\end{array}$ & $\begin{array}{c}3.13 \\
3\end{array}$ & $\begin{array}{c}0.45 \\
2\end{array}$ & $\begin{array}{c}20.60 * \\
3\end{array}$ & $\begin{array}{c}0.009 \\
2\end{array}$ & $\begin{array}{c}7.36 \\
3\end{array}$ & $\begin{array}{c}1.42 \\
1\end{array}$ & $\begin{array}{c}1.89 \\
3\end{array}$ \\
\hline
\end{tabular}

*significant Chi-square values $(\mathrm{P}<0.05)$ 
Table 4. Two-locus linkage disequilibrium analysis (LD) expressed as the number of loci with significant differences over the total pairwise loci comparisons, range of $I_{A}$ values after 1000 randomisations and observed Index of Association $\left(I_{A}\right)$. In the last column recombination is indicated as a 'yes' based on the observation that the observed $I_{A}$ value falls within the randomized dataset values.

\begin{tabular}{lcccc}
\hline & $\begin{array}{l}\text { LD } \\
\text { between } \\
\text { pairs of } \\
\text { loci }\end{array}$ & $\begin{array}{l}\text { Range of obtained } \mathrm{I}_{A} \\
\text { values after } 1000 \\
\text { randomizations }\end{array}$ & Obs. $I_{A}$ & $\begin{array}{l}\text { Obs. } I_{A} \text { within the } \\
\text { randomized data } \\
\text { range. (i.e. evidence } \\
\text { for recombination) }\end{array}$ \\
\hline $\begin{array}{l}\text { Argentina } \\
\text { Uruguay }\end{array}$ & $0 / 45$ & $-0.0005-0.33$ & 0.22 & Yes \\
All & $4 / 45$ & $-0.0066-0.13$ & $0.08^{*}$ & Yes \\
\hline
\end{tabular}

*significant $\mathrm{p}<0.05$ 